\title{
STOPPING HISTORY IN WALT WHITMAN'S DRUM-TAPS
}

\author{
Maire Mullins
}

WaLt WhitMan's DRUM-TAPS poems are set in a specific period of time, the Civil War. Yet throughout this poetic cluster the concept of historical time, ostensibly the subject matter of the poems, is stopped and frozen so that a different history, that of comradeship and homoerotic desire, may be told. This other history is related in a way that is simultaneously inside and outside the historical narrative of the Civil War: inside, because these scenes are placed within the poems of Drum-Taps; outside, because these scenes stop the larger story of the war and interject instead scenes of affection and love between men.

In Specimen Days, Whitman writes "the real war will never get in the books." However, his perspective as nurse and as poet gave him a unique vantage point that allowed much of the war and its aftermath to get into Leaves of Grass. His roles of witness, observer, recorder, healer, letter writer, comrade, and lover at times became conflated. He describes the difficult balance between the engagement required of the comrade and attentive healer and the detachment necessary for the nurse and the witness/recorder in the following way:

My place in Washington was a peculiar one; my reasons for being there; my doing there what I did do. I do not think I quite had my match. People went there for all sorts of reasons. . . . But no one-at least no one I met - went just from my own reasons, from a profound conviction of necessity, affinity, coming into closest relations-relations $\mathrm{O}$ so close and dear! - with the whole strange welter of life gathered to that mad focus. ${ }^{2}$

Whitman initially went south in order to locate his brother George, who was wounded at the Battle of Fredericksburg on December 13, 1862. Although the time spent with George (who was not seriously hurt) and George's regiment (about ten days) gave him valuable insights into life at the battlefront, what kept Whitman in Washington was the "affinity" and comradeship he felt for the wounded soldiers. In his letters, he used the term "magnetic" and "magnetism" to describe this attraction. In a letter to Abby Price dated October 11, 1863, Whitman writes: "Above all the poor boys welcome magnetic friendship, personality (some are so fervent, so hungering for this)... . O how one gets to love them, 
often, particular cases, so suffering, so good, so manly \& affectionate."3 Whitman viewed this rapport as more important than medical aid; he writes, "I find I supply often to some of these dear suffering boys in my presence \& magnetism that which nor doctors nor medicines nor skill nor any routine assistance can give."

In the pre-war Calamus poems Whitman had searched for ways to express this affection, feeling both a "need for caution" and a "fear of exposure." In "What Think You I Take My Pen in Hand?" Whitman challenges the reader to see what he sees, and to set aside conventional expectations about the subject matter of poetry. The poem splits in half neatly as Whitman juxtaposes contemporary readers' expectations with his own more daring and revolutionary program. The first half of the poem poses five questions to draw the reader in:

What think you I take my pen in hand to record?

The battle-ship, perfect-model'd, majestic, that I saw pass the offing to-day under full sail?

The splendors of the past day? or the splendor of the night that envelops me?

Or the vaunted glory and growth of the great city spread around me? - no . . . .

In this poem Whitman creates an occasion for collaborative reading. In order to answer the question posed in the title and in the poem's first line, the reader must discern, as the speaker of the poem does, the value of the simple exchange which takes place on the pier:

But merely of two simple men I saw to-day on the pier in the midst of the crowd, parting the parting of dear friends,

The one to remain hung on the other's neck and passionately kiss'd him, While the one to depart tightly prest the one to remain in his arms. ${ }^{6}$

The pier is a public place, and a large crowd has gathered to say their good-byes to their family members and loved ones. The larger scene of communal departure contains within it the smaller scene of two men parting. Because it is enveloped within the melee of parting, homoerotic love and affection can be expressed without calling attention to itself or being recognized as a threat to the dominant social order. The feelings the two men have for each other, however, are discerned by the poem's speaker, who sees what others do not, will not, or cannot see. The speaker reads the scene, the poet records it, and the reader is then challenged to set aside regard for the impressive monuments of the present time, the "majestic" battleship, the "glory and growth of the great city," the "splendors of the past day," and to recognize instead the significance of this small but telling episode on the pier. The first three words of the poem's title, "What Think You," arrest the reader's attention, just as the two men in the midst of the crowd arrest the speaker's attention. The larger narrative of parting contains within it this moment of pause. The poet 
deliberately sets aside the subject matter of poetic discourse and instead interjects and replaces it with this simple scene of love and affection, a scene which portends much in Whitman's thinking about the future of the United States. In "To the East and to the West," the next poem of the cluster, Whitman writes, "I believe the main purport of these States is to found a superb friendship, exaltè, previously unknown, / Because I perceive it waits, and has been always waiting, latent in all men" (401).

The Calamus motif in the Drum-Taps poems has been noted, but it is more prevalent and more interlaced in the poems than previous commentary suggests. ${ }^{7}$ The collection as a whole has been divided into "reveille" poems and "wound-dresser" poems, ${ }^{8}$ or categorized as "the earlier martial poems" and "the famous elegies and memorial poems." M. Jimmie Killingsworth notes that "in the former, the union is identified with the self, and the poet urges strong young men to gather their energies for a struggle of survival. In the latter, the union is the other, to whom the poet gives himself lovingly and with whom the poet seeks to merge." 10 Joseph Cady draws a distinction between the poems of Calamus and Drum-Taps. He writes, "There are important echoes of Calamus throughout these Drum-Taps pieces, and I believe they must be understood in the same way as the earlier collection. But Whitman's main vehicles in these Drum-Taps poems differ. Emerging directly out of the war setting itself, the chief means through which he makes a homosexual statement here are the motif of 'solder-comradeship' and the elegy convention." 11 In the Drum-Taps poems, the War and its accoutrements, hospitals, and camp grounds serve as the settings for contact with comrades and lovers. Whitman writes:

These [division hospitals] are merely tents, and sometimes very poor ones, the wounded lying on the ground, lucky if their blankets are spead on layers of pine or hemlock twigs, or small leaves. No cots; seldom even a mattress. It is pretty cold. The ground is frozen hard, and there is occasional snow. I go around from one case to another. I do not see that I do much good to these wounded and dying; but I cannot leave them. Once in a while some youngster holds on to me convulsively, and I do what I can for him; at any rate, stop with him and sit near him for hours, if he wishes it. ${ }^{12}$

The very title of this collection of Civil War poetry, Drum-Taps, suggests a moment in time: the tap of the drum, a finite sound. What these taps signify, however, changes not only from poem to poem but also, sometimes, within the body of the poem itself. ${ }^{13}$ This gradation is due to the unique manner in which Whitman composed and revised these poems during the years spanning the Civil War. Each Drum-Taps poem, then, represents not just a singular moment in time, but also serves as a touchstone for the shifts of emotion and mood Whitman experienced as he lived through the war and as his own sense of vocation changed. 
In many of the Drum-Taps poems, Whitman freezes time and injects a tableau; this tableau is often part of a larger catalogue, scene, section of the poem, or poem sequence, but is nevertheless separated from the main action or flow of ideas. The larger historical momentthe movement of troops across a ford or down into a valley, the memories of the revolutionary war set forth by a centenarian, the death of a comrade-is preserved in the texts of the poems, but desire is expressed in stopped time. ${ }^{14}$ These moments are bracketed from the context of the war and become venues for the speaker's expression of desire for those whom he lovingly addresses, describes, remembers, exchanges glances with, touches. This desire is sometimes reciprocated or acknowledged, and other times it is not: the expression alone suffices. Whitman creates these tableaus so that the continuum of homoerotic desire might be incorporated into the text of the poems in a nonthreatening manner, just as in the Calamus poems he set this continuum in crowded public places or in secluded landscapes, and used slant language to mask meaning.

The first poem of the collection, "First O Songs for a Prelude" (originally entitled "Drum-Taps") describes the city of "Mannahatta" awakening from its peaceful slumber in response to "news from the south" (453) about the firing on Fort Sumter-"A shock electric." An extensive catalogue in the middle of the poem captures the sense of urgency and immediate response present everywhere in the city:

To the drum-taps prompt,

The young men falling in and arming,

The mechanics arming, (the trowel, the jack-plane, the blacksmith's hammer, tost aside with precipitation,)

The lawyer leaving his office and arming, the judge leaving the court,

The driver deserting his wagon in the street, jumping down, throwing the reins abruptly down on the horses' backs,

The salesman leaving the store, the boss, book-keeper, porter, all leaving;

Squads gather everywhere by common consent and arm. . . . (454)

The news of the war infuses a common sense of purpose into the city's population, a purpose that cuts across class and gender lines. Mechanics, lawyers, judges, drivers, salesmen all desert their tasks in order to serve. Mothers kiss their newly enlisted sons good-bye, and women volunteer for nursing jobs. The everyday routine of the working world is dramatically interrupted and tossed aside. Yet, amongst all this activity, Whitman injects a brief vignette describing the men as they tramp by in their regiments:

(How good they look as they tramp down to the river, sweaty, with their guns on their shoulders!

How I love them! how I could hug them, with their brown faces and their clothes and knapsacks cover'd with dust!) (454) 
The parentheses which enclose these two lines give added emphasis to their separateness from the catalogue in which they are contained, and stop the flow of the narrative. The speaker interrupts and suspends the larger movement of the poem, which is about the city's sudden preparation for war, and focuses instead on the physical attractiveness of the soldiers. These two lines depart from the immediate subject matter of the poem and thus represent an arrest of linear time. The commencement of the Civil War is itself a rupture in the fabric of daily life for this large city. The transition from peace to war is sudden: the rapid pace quickly results in the creation of a new way of thinking about time among the people. The regiments of soldiers serve as a trope for this changed perception: last night it was peacetime; it is now wartime. Their assembly and departure provide the speaker with an opportunity to suspend the narrative of the poem while he inscribes his own homoerotic feelings for them, even as he admires their willingness to serve, their resolution, and their volunteerism.

This focus on the bodies of the soldiers as they march by continues in the next poem of the collection, "Eighteen Sixty-One." 15 Time again becomes a central preoccupation of the speaker as the poem captures the confusion and emotion of the first year of war. The year is finitely contained within the boundaries of the number spelled out as the poem's title. Whitman later described his method of composing some of the Drum-Taps poems as immediate, on the spot:

"I took the first scrap of paper, the first doorstep, the first desk, and wrote, wrote, wrote. No prepared picture, no elaborated poem, no after-narrative could be what the thing itself was. .. . You want to catch the first spirit, to tally its birth. By writing at the instant, the very heartbeat of life is caught."16

When the poem "Eighteen-Sixty-One" was composed, however, Whitman had not yet been to Washington; he was removed from "the real war," although he was not aware of it. Thus, the year is personified as an idealized soldier/poet:

But as a strong man erect, clothed in blue clothes, advancing, carrying a rifle on your shoulder,

With well-gristled body and sunburnt face and hands, with a knife in the belt at your side,

As I heard you shouting loud, your sonorous voice ringing across the continent,

Your masculine voice $\mathrm{O}$ year, as rising amid the great cities. . . . (4-7)

Indeed, this passage comes very close in its manner of depicting the male body to what Whitman had written six years before, in "I Sing the Body Electric": 
The expression of the face balks account,

But the expression of a well-made man appears not only in his face,

It is in his limbs and joints also, it is curiously in the joints of his hips and wrists,

It is in his walk, the carriage of his neck, the flex of his waist and knees, dress does

not hide him,

The strong sweet quality he has strikes through the cotton and broadcloth,

To see him pass conveys as much as the best poem, perhaps more,

You linger to see his back, and the back of his neck and shoulder-side. (122)

Whitman's technique of incorporating a loving description of the physical beauty of the male body in motion extends from the first edition of Leaves of Grass into this early poem of the Drum-Taps cluster. The first year of the war is portrayed as a hyper-masculine soldier marching off to war, whose impressive physical presence and voice span the continent. After Whitman visited his brother George and took up residence in Washington D.C., this manner of depicting the war changed. In "Quicksand Years" (1862-1863) and "Year that Trembled and Reel'd Beneath Me" (perhaps 1863-1864) the speaker describes instead the sense of war-weariness and confusion that have set in:

Year that trembled and reel'd beneath me!

Your summer wind was warm enough, yet the air I breathed froze me,

A thick gloom fell through the sunshine and darken'd me,

Must I change my triumphant songs? said I to myself,

Must I indeed learn to chant the cold dirges of the baffled?

And sullen hymns of defeat? (505)

The war is no longer lovingly personified as a soldier-poet, and the chanter of these poems must learn the "dirges of the baffled." Whitman did not write or publish many poems in the first two years of the war, which, as Betsy Erkilla notes, "may ... reflect his uncertainty about the role of a national poet in a period of fratricidal war." 17 He wrote "First O Songs for a Prelude," "Eighteen Sixty-One," and "Beat! Beat! Drums!" from a distance. As Jerome Loving points out, "the tone" in Drum-Taps "shifts from the excitement of going to war to the recognition of the war's frightening toll on the American 'camerado'." 18 Time is no longer portrayed as linear; in these poems it is fractured and unstable, "Quicksand years that whirl me I know not whither."

"The Wound Dresser" is one of Whitman's most lovingly rendered testimonies to the men he tended during the war. Framed by the present-the time of the reader, post-war time-the poem moves into the past through the memory of the old man who speaks of his experiences. The poem ends with a passage enclosed in parenthesis which is similar to the lines from "First O Songs for a Prelude": "(Many a soldier's loving arms about this neck have cross'd and rested, / Many a soldier's kiss dwells on these bearded lips.)" (482). Instead of the loving, admiring glance directed toward the soldier's bodies from a distance, how- 
ever, these lines describe direct physical contact that is reciprocal and reciprocated. The wound dresser becomes the repository of those caresses and kisses, and represents a physical connection to the dead soldiers and their last loving gestures. Both the wound dresser and the speaker of the earlier poem are present at boundary moments in the soldiers' lives: watching them march proudly off to war as the conflict begins, and watching them depart bravely into death. These two moments are connected by their speakers' love for and admiration of the soldiers. In both poems, time is arrested so that these scenes can be inserted.

"O Tan-Faced Prairie-Boy" describes the silent exchange that takes place between two men in a camp:

O tan-faced prairie-boy,

Before you came to camp came many a welcome gift,

Praises and presents came and nourishing food, till at last among the recruits,

You came, taciturn, with nothing to give-we but look'd on each other,

When lo! more than all the gifts of the world you gave to me. (507)

The poem's speaker, a resident of the camp, directly addresses the "tanfaced prairie-boy," a newcomer. A system of exchange had already been established in which "many a welcome gift, / Praises and presents came and nourishing food." After the tan-faced boy's arrival, this system no longer suffices; the gifts that were given were "welcome," but they did not provide the sustenance that the speaker hungers for-contact with a loving comrade. "Taciturn, with nothing to give" the new recruit paradoxically brings the most precious and most welcome gift, the gift outside of language, which signifies "more than all the gifts of the world" to the speaker. This gift is given within the span of a simple exchange of glances: "we but look'd on each other." At this moment a mutual understanding is passed back and forth. The gaze signifies the stopping of history; the speaker's understanding of camp life, of all that came before the "prairie-boy's" arrival, is arrested and set aside. A new system of comradely exchange is instituted, and the speaker's life changes instantly. In subject matter and tone, this poem is remarkably similar to a poem in the Calamus cluster, "A Glimpse":

A glimpse through an interstice caught,

Of a crowd of workmen and drivers in a bar-room around the stove late of a winter night, and I unremark'd seated in a corner,

Of a youth who loves me and whom I love, silently approaching and seating himself near, that he may hold me by the hand,

A long while amid the noises of coming and going, of drinking and oath and smutty jest,

There we two, content, happy in being together, speaking little, perhaps not a word. (397) 
The speaker of the poem simultaneously places himself on the inside and the outside of the bar, creating a split between the "I" who catches this intimate glimpse and the "I" seated within who meets his lover. The poem represents a verbal glimpse of nonverbal communication: amid the noise, the two lovers quietly hold hands. The speaker, "unremark'd," unnoticed by the patrons of the bar, is "seated in a corner," a marginal position, withdrawn and semi-concealed, but also a vantage point. Surrounded by "drinking and oath and smutty jest" the lovers communicate through the proximity of their bodies. Theirs is an intimacy created not through language conventions but through nearness and touch.

The word "vigilia" in Latin means "awake," and the term "vigil" is often used to refer to the eve of a religious holy day, that time of alert watchfulness and hopeful anticipation. In the poem, "Vigil Strange I Kept on the Field One Night," Whitman describes a different kind of vigil, one kept on the battlefield by a soldier for his mortally wounded comrade: "One look I but gave which your dear eyes return'd with a look I shall never forget, / One touch of your hand to mine $\mathrm{O}$ boy, reach'd up as you lay on the ground" (491). James E. Miller notes that these lines "suggest the depth of the 'Calamus' feeling that binds the two soldiers in comradeship."19 "Late in the night" the soldier returns to find his comrade "in death so cold" and he passes the "sweet hours" of the night with the body, "Vigil wondrous and vigil sweet there in the fragrant silent night" (492). The larger drama of the war is suspended as Whitman focuses on this compelling scene, repeating the word "vigil" throughout, lending a spiritual quality to the poem and to the nature of the relationship between the two soldiers. Nighttime's silence and solitude replace the frenzied movement of daytime / wartime. The soldier's reverent and loving wakefulness over the body of his slain comrade provides telling and eloquent commentary on the bond between the two men. The speaker refers to the fallen soldier as "my son and my comrade," which suggests an age difference between the two men as well as a paternal relationship. The older soldier is protective of his young comrade even after death, silently watching over his body as the night goes by, and then "folded [him] well in his blanket, / And buried him where he fell" (492). This poem marks a new direction in Whitman's homoerotic poetry, a shift in the relationship between lover and beloved. Age now becomes more pronounced; usually the lover / speaker is older. Loving, noting the "poet's avuncular impulses" and "expressions of empathy" in the Drum-Taps poems, suggests that "the poet's desire for male friendship (or lovers) may have shifted to a desire for sons," but this is not the case. ${ }^{20}$ "Vigil Strange I Kept on the Field One Night" combines the erotic and the paternal, and foreshadows the kind of relationships that Whitman would have with younger men in the last decades of his life. Whitman continued to attract and to be attracted to 
younger men, for friendship and for love. What changes in Drum-Taps is the acknowledgement of this age difference, and the incorporation of it in the poems.

In "As Toilsome I Wander'd Virginia's Woods," Whitman describes an inscription he notices "On a tablet scrawl'd and nail'd on the tree by the grave, / Bold, cautious, true, and my loving comrade" (509). These words provide public testimony to the nature of the relationship between two comrades - bold, yet cautious, true, and, most importantly of all, loving. In the first stanza the speaker is wandering the Virginia woods, perhaps exhausted, certainly tired, when he notices a grave, and reads the situation: "I mark'd at the foot of a tree the grave of a soldier; / Mortally wounded he and buried on the retreat (easily all could I understand)" (509). The speaker, although not present at the scene of death, "easily" comprehends the nature of the relationship between the two men. The words are not easily forgotten, however, and come back to the speaker in a different time and place:

Long, long I muse, then on my way go wandering

Many a changeful season to follow, and many a scene of life,

Yet at times through changeful season and scene, abrupt, alone, or in the crowded street,

Comes before me the unknown soldier's grave, comes the inscription rude in Virginia's woods,

Bold, cautious, true, and my loving comrade. (509-510)

In a sense, these words become a touchstone for the War as Whitman experienced it. Later, he wrote:

And truly, who is not directly [?] interested in these same hospitals? What family, what man, what woman, in any city or State, has not some relative or friend, or at least some one whom he or she has formerly seen and talked with in health, now wounded or sick, amid these suffering soldiers? Nor is the sight a repelling one only. There is enough to repel, but [illeg.] one soon becomes powerfully attracted also. ${ }^{21}$

Throughout Drum-Taps, then, the larger historical narrative of the Civil War is punctuated by moments of stopped time; war time is frozen and a scene, a few lines, or a tableau of homoerotic exchange is inserted. The narrative of the Civil War, ostensibly the subject matter of these poems, is set aside temporarily so that the narrative of homoerotic desire and loving comradeship so crucial to Whitman's experience of war-time can be included. The nature of the relationships depicted in these poems changes from idealized, hyper-masculine soldiers, to slain comrades, to young soldiers cut down yet beloved, to the paternal indicative of the direction Whitman's own relationships would take in the decades after the Civil War. 


\section{NOTES}

1 Prose Works 1892, ed. Floyd Stovall (New York: New York University Press, 1963), $1: 116$.

2 Walt Whitman's Civil War, ed. Walter Lowenfels (New York: Knopf, 1960), 14.

3 The Correspondence: 1842-1867, ed. Edwin Haviland Miller (New York: New York University Press, 1961), 1:162. Hereafter Corr.

4 Corr. 1:159. Jerome Loving notes that "although Whitman took an active part in assisting physicians in the war . . . much of his talent as 'nurse' probably lay in the area of psychology, in engaging the former farmboys and city laborers as 'dear friends' instead of patients" "Caresser of Life: Walt Whitman and the Civil War," Walt Whitman Quarterly Review 15 [Fall 1997/Winter 1998], 75).

5 Alan Helms, “Hints . . F Faint Clews and Indirections': Whitman's Homosexual Disguises," Walt Whitman Here and Now, ed. Joann P. Krieg (Westport, Connecticut: Greenwood Press, 1985), 62.

6 Leaves of Grass: A Textual Variorum of the Printed Poems, ed. Sculley Bradley, Harold W. Blodgett, Arthur Golden, and William White (New York: New York University Press, 1980), 2:399-400. Subsequent references to Leaves of Grass are to this edition and will be cited parenthetically in the text.

7 See Timothy Sweet, Traces of War: Poetry, Photography, and the Crisis of the Union (Baltimore: Johns Hopkins University Press, 1990), for a discussion of "the four topoi of the Unionist rhetoric which legitimated the prosecution of the Civil War" (11-12). In section five, entitled the "unifying, democratic love of comrades-at-arms," Sweet focuses on Drum-Taps, but not in the context of a continuum from Calamus.

8 See De Wolfe Miller, Walt Whitman's Drum-Taps and Sequel to Drum-Taps: A Facsimile Reproduction (Gainesville, Florida: Scholar's Facimiles \& Reprints, 1959), vii.

9 See Michael Moon, Disseminating Whitman: Revision and Corporeality in Leaves of Grass (Cambridge: Harvard University Press, 1991), 172. Moon notes, "Even more so than in the 1860 'Calamus' poems of male-homoerotic love and community, the 'Drum-Taps' poems (both the 'enthusiastic' ones and the elegiac ones) foreground human bodiliness to a high degree. They are written 'closer to the body,' so to speak, than perhaps any other group of poems in Leaves of Grass" (173).

10 M. Jimmie Killingsworth, Whitman's Poetry of the Body (Chapel Hill: University of North Carolina Press, 1989), 136.

11 “Drum-Taps and Nineteenth-Century Male Homosexual Literature," in Walt Whitman Here and Now, 50.

12 Cited in Gay Wilson Allen, The Solitary Singer (Chicago: University of Chicago Press, 1955), 285.

13 In his introduction to the facsimile edition of Drum-Taps, Miller writes that "It was not by the bugle but by the drum (and thus the word taps) that the military taps were first sounded. The word was already in use by the time of the war, but tattoo was the common term; even as late as 1888 Whitman, though he knew the meaning well, was not quite sure that he did. On the death of Sheridan in that year Whitman had sent an elegiac poem, 'Interpolations,' to the New York Herald. Numerous other papers copied it, substituting their own title, 'Taps.' Whitman, who at that moment appeared to be mortally ill himself, asked Traubel, 'What are taps? I have a dim notion of the truth in my brain but I am not confident I know. I want you to ask the first 
soldier you meet. ... As I guess at it now it is a . . last sort of ceremony before turning in - the final message of the drums before sleep. It has a certain kind of solemn significance" (vii).

14 Kenneth M. Price notes that Whitman in his work was "not simply rejecting heavily metaphoric language but was trying to establish a new relationship between poetry and time" (Whitman and Tradition: The Poet in His Century [New Haven: Yale University Press, 1990], 22).

15 "Eighteen Sixty-One" was originally the sixth poem in the collection. Whitman moved it to its present location in 1871 and trimmed Drum-Taps from 53 to 32 poems. Anthony Szczesiul writes that although the "montage effect of the 1865 edition is lost [in the 1871 edition] due to the relocation of the majority of the unwarlike pieces, it has been replaced by what may be called a narrative sequencing of the remaining thirty-two" ("The Maturing Vision of Walt Whitman's 1871 Version of Drum-Taps," Walt Whitman Quarterly Review 10 [Winter 1993], 130-131).

16 Walt Whitman's Civil War, 14.

17 Whitman the Political Poet (Oxford: Oxford University Press, 1989), 196.

18 Loving, 81.

19 James Edwin Miller, A Critical Guide to Leaves of Grass (Chicago: University of Chicago Press, 1957), 158.

20 Loving, 81.

21 Notebooks and Unpublished Prose Manuscripts, ed. Edward F. Grier (New York: New York University Press, 1984), 2:591. 